\title{
Marta BALCEREK
}

Poznań

\section{Ustrój prawny samorządu rolniczego w Polsce i RFN. Studium porównawcze}

$\mathbf{W}$ Europie wykształciły się dwa modele izb gospodarczych: model francuski oraz model anglosaksoński. Pierwszy z nich, zwany inaczej kontynentalnym, charakteryzuje się obligatoryjnym członkostwem, drugi natomiast opiera się na dobrowolnym modelu członkostwa. W modelu francuskim, izby samorządowe to korporacje publicznoprawne, które z mocy ustawy posiadają obligatoryjny charakter członkostwa. Obejmują one wszystkich przedsiębiorców danej dziedziny gospodarki lub dziedzin pokrewnych działających na obszarze izby, bez względu na ich wolę. W drugim modelu, członkostwo ma charakter fakultatywny. Izby funkcjonuja wtedy jako elitarne organizacje zawodowe różnych grup interesu, bez władztwa administracyjnego. W Polsce, w odniesieniu do izb rolniczych, funkcjonuje model mieszany - izby rolnicze zostały wyposażone w obligatoryjne członkostwo, ale bez władztwa administracyjnego.

I.

Legitymizacja samorządu rolniczego jako organu państwa została uregulowana w ustawie zasadniczej. W przypadku RFN całość spraw związanych z powoływaniem izb rolniczych, ich organizacją i funkcjonowaniem jako podmiotów zdecentralizowanej administracji publicznej została - na mocy Konstytucji federalnej (art. 30 i 83) ${ }^{1}$ - przeniesiona na kraje związkowe. Każdy land posiada zatem własne regulacje prawne dotyczące izby rolniczej na jego terenie ${ }^{2}$.

Pierwszym aktem prawnym, który wprowadził izby rolnicze w Republice Federalnej Niemiec była ustawa Landtagu Północnej Nadrenii-Westfalii z 11 lutego 1949 r. ${ }^{3}$ Na mocy tej ustawy powstała pierwsza w RFN Izba Rolnicza Północnej Nadrenii-Westfalii. Ustawa ta stała się wzorem dla innych landów, które miały potrzebę powołania na swoim obszarze izby rolniczej ${ }^{4}$. Wzorem tej ustawy niemieckie izby rolnicze są korporacjami prawa publicznego,

\footnotetext{
${ }^{1}$ Art. 30 realizacja uprawnień władzy państwowej $i$ wykonywanie zadań państwowych należy do władz krajów zwiqzkowych o ile ustawa zasadnicza nie stanowi inaczej lub nie dopuszcza innych regulacji prawnych. Art. 83. Stanowi, że kraje zwiazkowe wykonuja ustawy federalne jako własna sprawe, o ile ustawa zasadnicza nie stanowi inaczej lub nie dopuszcza innej możliwości.

${ }^{2}$ Regulacje prawne dotyczące powoływania izb rzemieślniczych zostały zawarte w ustawie z dnia 17.09.1953 roku o rzemiośle ze zmianami; Gesetz zur Ordnung des Handwerks v. 17.09.1953, BGB1 I 1953, 1411; Gesetz zur Ordnung des Handwerks v. 24. 9.1998 I 3074, v. 11.12.2008 I 2418.

${ }^{3}$ Gesetz über Landwirtschaftskammer Nordrhein-Westfalen v. 11.2.1949, GV NW. S. 53. 23.12.2003, GV NW. S. 808 .

${ }^{4}$ A. Werenowska, Organizacja izb rolniczych wybranych krajach UE, Zeszyty Naukowe Akademii Rolniczej im. H. Kołłątaja w Krakowie, z. 78, nr 377, Kraków 2000, s. 424.
} 
a przynależność do nich jest obligatoryjna ${ }^{5}$; dzięki tym konstytutywnym cechom izby rolnicze posiadają władztwo administracyjne, czyli zdolność do wykonywania określonych w ustawie zadań w dziedzinie rolnictwa ${ }^{6}$; są podobnie jak izby przemysłowo-handlowe i rzemieślnicze podmiotami zdecentralizowanej administracji publicznej w pewnej przestrzeni $\dot{z} y$ ciowej, w której funkcjonuja, tą „przestrzenią” jest rolnictwo ${ }^{7}$.

Inaczej jest w Polsce. Po transformacji systemowej ustrój prawny izb rolniczych został uregulowany w ustawie o izbach rolniczych z 14 grudnia 1995 r., która wyróżniła izby rolnicze spośród pozostałych izb samorządowych, nadając im atrybut obligatoryjności ${ }^{8}$. Następnie w art. 17 ust. 2 Konstytucji RP ${ }^{9}$ ustawodawca dopuścił możliwość utworzenia innego rodzaju samorzqdu (czyli także samorządu rolniczego); jednakże nie uregulował on jego formy organizacyjno-prawnej. Skutkiem tego było powołanie izb rolniczych o obligatoryjnym członkostwie, ale bez władztwa administracyjnego; nie zajmują one pełnoprawnej pozycji przedstawiciela środowiska rolniczego w relacjach z administracją publiczną. Ustawa z $1995 \mathrm{r}$. przewidywała powstanie izby rolniczej na terenie każdego województwa, czyli łącznie funkcjonuje w Polsce 16 izb.

$\mathrm{Z}$ kolei niemieckie izby rolnicze nie mają charakteru powszechnego. Oprócz 7 izb rolniczych nie funkcjonują instytucje samorządu gospodarczego w sferze rolnictwa ${ }^{10}$. Np. w Bawarii w celu ochrony interesów osób fizycznych i prawnych związanych z rolnictwem powstał, w wyniku dekoncentracji administracji publicznej tego kraju związkowego, urząd rolniczy (Landesanstalt fuer Landwirtschaft) ${ }^{11}$ stanowiący część tej administracji bez samodzielnego władztwa administracyjnego i nieposiadający charakteru instytucji samorządu go-

${ }^{5}$ Por. $§ 20$ ust. 1 ustawy o Izbie Rolniczej Pótnocnej Nadrenii-Westfalii z 11 lutego 1949 r. stwierdza, że izby rolnicze posiadają osobowość publicznoprawną oraz obligatoryjne członkostwo; szerzej: W. Frotscher, U. Kramer, Wirtschaftsverfassungs - und Wirtschaftsverwaltungsrecht..., op. cit., s. 295. W § 23 ust. 4 ustawy o organizacji samorzq̨u rolniczego w Pólnocnej Nadrenii-Westfalii z 10.07.1962 r., wskazano jednoznacznie, że izby rolnicze są podmiotami prawa publicznego, Gesetz über die Organisation der Landverwaltung vom 10.7.1962, GV NW S. 241, zmieniona przez ustawę z 9.5.2000, GV NW S. 462.

${ }^{6} \mathrm{~W}$ niemieckiej nauce prawnej kontrowersje wokół podmiotowości publicznoprawnej izb rolniczych budziło wykonywanie funkcji przedstawicielskiej środowiska rolniczego przez izby. Europejski Trybunał Sprawiedliwości wydał w tej sprawie orzeczenie klasyfikując izby rolnicze, izby przemysłowo-handlowe, izby rzemieślnicze, izby ubezpieczeniowe etc. jako związki przedsiębiorców. Tymczasem w Konstytucji Republiki Federalnej Niemiec z dnia 23 maja 1949 roku nie została wyraźnie wskazana gwarancja powołania oraz funkcjonowania izb. Na podstawie art. 30 i 83 niemieckiej ustawy zasadniczej przeniesiono uprawnienie tworzenia izb na kraje związkowe, por. K. Stollreither, Verfassung des Freistaates Bayern. Grundgesetz fuer die Bundesrepublik Deutschlands. Ueberblick ueber Europaeische Union. Der Bayerische Landtag. Funktionen und Aufgaben, Augsburg 2007, s. $132-161$.

${ }^{7}$ R. Stasikowski, Gwarancje samorzadności gminnej w systemie prawnym Republiki Federalnej Niemiec i Rzeczypospolitej Polskiej, s. 19; por. R. Hendler, Geschichte und Idee der funktionalen Selbstverwaltung, w: Handbuch des Kammerechts, pod red. W. Kluth, Halle 2005, s. 25. Jak wiadomo, Republika Federalna Niemiec należy do najwyżej uprzemysłowionych i zurbanizowanych państw świata. W 2004 r. około 88\% ludności tego kraju zamieszkiwało w miastach, a $12 \%$ na wsi. W związku z tym, o ile izby przemysłowo-handlowe działają we wszystkich 16 krajach związkowych, to izby rolnicze zaledwie w 7; odpowiednio izb przemysłowo-handlowych funkcjonuje w Niemczech 83, a izb rolniczych zaledwie 7. Przeciętna liczba członków niemieckiej izby rolniczej liczy ok. 200 tys. członków. Dodać należy, że w krajach związkowych wchodzących przed zjednoczeniem Niemiec do Niemieckiej Republiki Demokratycznej nie powołano dotąd żadnej korporacji samorządu rolniczego.

${ }^{8}$ Ustawa z 14 grudnia 1995 r. o izbach rolniczych, Dz. U. Nr 1, poz. 3 z późn. zm.

${ }^{9}$ Konstytucja Rzeczypospolitej Polskiej z dnia 2 kwietnia 1997 r., Dz. U. Nr 78, poz. 483.

${ }^{10}$ Izba Rolnicza w Północnej Nadrenii-Westfalii (1949 r.), Izba Rolnicza w Bremen (1956 r.), Izba Rolnicza w Rheinland-Pfalz (1970 r.), Izba Rolnicza w Zagłębiu Saary (1975), Izba Rolnicza w Hamburgu (1990), Izba Rolnicza w Szlezwiku-Holsztynie (1997 r.), Izba Rolnicza w Dolnej Saksonii (2003 r.).

${ }^{11}$ W. Kluth, Entwicklungsgeschichte und aktuelle Rechtsgrundlagen der kammern im Ueberblick, w: Handbuch des Kammerrechts, pod red. W. Kluth, Halle 2005, s. 273. 
spodarczego. Podobne do zadań izby rolniczej wykonują w Bawarii: urząd rolniczy, urząd do spraw leśnictwa i urząd do spraw hodowli roślin i winorośli wyodrębnione w ramach struktur ministerstwa żywności, rolnictwa i leśnictwa Bawarii, czyli resortu administracyjnego kraju związkowego ${ }^{12}$.

Jak już wspomniano, niemiecka ustawa zasadnicza (1949 r.) swoje uprawnienia w kwestii powoływania izb rolniczych, ich organizacji i zadań delegowała na kraje związkowe. Należy jednak zaznaczyć, że nie wszystkie konstytucje krajów związkowych zawierają kompletny katalog norm prawnych odnoszący się do ustroju izb rolniczych ${ }^{13}$. Wspomnieliśmy wyżej, że komplet takich norm prawnych, regulujących zasady tworzenia i funkcjonowania izb rolniczych zawiera jedynie ustawa o izbie rolniczej Północnej Nadrenii-Westfalii ${ }^{14}$. Na tej ustawie wzorują się często inne izby rolnicze w Niemczech.

W ustawodawstwie polskim oraz niemieckim istota samorządności izb rolniczych, podobnie jak wszystkich innych instytucji samorządu w rozumieniu teorii prawa administracyjnego, polega na zasadzie „,Betroffenenmitwirkung”, czyli udziale osób w sprawach, które ich bezpośrednio dotyczą. Zasada ta ma związek z definicją istoty samorządu wprowadzoną do nauki prawa administracyjnego przez Georga Jellinka, który przez pojęcie samorządu rozumiał samodzielne wykonywanie zarzadu przez bezpośrednio zainteresowane osoby ${ }^{15}$.

Zgodnie z doktryną prawa administracyjnego izby rolnicze wykonują własne zadania i zlecone z zakresu administracji publicznej. W przypadku jednych i drugich zadań izby ponoszą pełną odpowiedzialność za ich wykonywanie (Eigenverantowortlichkeitsprinzip). Zgoda na samodzielne i odpowiedzialne realizowanie zadań własnych oraz zleconych przez izbę oznacza, że żaden inny organ administracji państwowej, włącznie z organami administracji rządowej i samorządowej, nie może ingerować ani zmieniać decyzji izby ${ }^{16}$. Na tym polega istota samorządu, wszystkich jego desygnatów, w tym również samorządu rolniczego. W związku z tym nadzór nad izbami rolniczymi ogranicza się jedynie do kryterium legalności, czyli wykonywania zadań zgodnie z prawem ${ }^{17}$.

Inaczej jest w przypadku izb rolniczych w Polsce, gdzie zgodnie z art. 5 ust. 2 i 3 ustawy z 1995 r. o izbach rolniczych przewiduje się możliwość wykonywania zadań zleconych z za-

${ }^{12}$ Równocześnie obok urzędu rolniczego funkcjonuje jako podmiot publicznoprawny Bawarski Związek Właścicieli Gruntów Rolnych, który odrodził się 7.09.1945 r. (mający tradycje w Bawarskiej Izbie Właścicieli Wielkich Majątków Ziemskich powołanej jako korporacja publicznoprawna z władztwem administracyjnym w 1920 r.). Podkreślić należy, że w 1970 r. Izba rolnicza Hesji, jako 8, została zlikwidowana przez włączenie jej do Izby Rolniczej w Hamburgu; Aufloesung der Landwirtschaftskammer in Hessen, Gesetz v. 22.07. 1969, GVB1 S. 142.

${ }^{13}$ Częstą praktyką w konstytucjach landów, w których powołano izbę rolniczą, jest zamieszczanie pojedynczych artykułów regulujących ustrój prawny izby. Przykładem może być Konstytucja Zagłębia Saary, w której do izb odnosi się tylko art. 59, w którym wskazano na zamknięty katalog podmiotów publicznoprawnych samorządu specjalnego, W. Kluth, Funktionale Selbstverwaltung, Halle 1997, s. 325; natomiast pozostałe normy odnoszące się do izb rolniczych mające swoją genezę w prawach, wolnościach oraz obowiązkach konstytucji RFN odzwierciedla to np. Konstytucja Saksonii-Anhaltu w art. 87 ust. 5.

${ }^{14}$ Działalnością, organizacją organów i zadaniami izb zajmuje się, wyodrębnione w ramach prawa administracyjnego, prawo izb - Kammerrecht.

${ }^{15}$ S. Wykrętowicz, Samorzad jako wyraz demokracji obywatelskiej, w: Samorzad w Polsce. Istota, formy, zadania, pod red. S. Wykrętowicza, Poznań 2008, s. 24.

${ }_{16}$ Do zasad, które legły u podstaw izb rolniczych w RFN zalicza się także zasadę subsydiarności. W art. 2. ustawy z 11 lutego 1949 wskazano, że izba w ramach utrzymywania i wzmacniania sektora rolnictwa w landzie zajmuje się wspieraniem rolnictwa na jego obszarze oraz opieką osób zatrudnionych w tym sektorze.

${ }^{17}$ Por. W. Kluth, Entwicklungsgeschichte und aktuelle Rechtsgrundlagen..., op. cit., s. 38; gwarancję wykonywania zadań własnych przez samorząd na własną odpowiedzialność oraz w ramach ustaw zawarto np. w Konstytucji Dolnej Saksonii w art. 57, a w Konstytucji Badenii-Wuertembergii w art. 71. 
kresu administracji rządowej lub samorządu terytorialnego, przekazanych w drodze ustaw lub na podstawie porozumień oraz zadań własnych, przekazanych w drodze porozumień - są w praktyce martwe. Ustawy z 5 czerwca 1998 r. o administracji rządowej w województwie; ustawa z dnia 5 czerwca 1998 r. o samorządzie powiatowym ${ }^{18}$, ustawa z dnia 5 czerwca $1998 \mathrm{r}$. o samorządzie województwa ${ }^{19}$, a także ustawa z 8 marca 1990 r., o samorządzie gminnym ${ }^{20}$ nie przewidują możliwości powierzenia izbom rolniczym żadnych zadań przez organy rządowe i samorządowe. Na tej podstawie można stwierdzić, że nie wydaje się możliwe wykonywanie zadań zleconych z zakresu administracji rządowej.

II.

Działalność izby rolniczej obejmuje wiele sektorów i branży, które stanowią obszar jurysdykcji izby. Na przykład Izba Rolnicza Północnej Nadrenii-Westfalii obejmuje następujące branże: rolnictwo, hodowla roślin, hodowla zwierząt, ogrodnictwo, uprawa warzyw, uprawa owoców, uprawa winorośli, leśnictwo, rybołówstwo śródlądowe i pszczelarstwo. Ponadto do izb należą także przedsiębiorstwa, które wprawdzie nie działają w wyżej wymienionych branżach, ale pozostają w stosunku zależności od nich.

Porównując zakres przedmiotowy działalności Wielkopolskiej Izby Rolniczej i Izby Rolniczej Północnej Nadrenii-Westfalii można dokonać następującego podziału zadań: po pierwsze, zadania opiniodawczo-doradcze; pod drugie, zadania o charakterze informacyjnym oraz po trzecie, zadania w celu wykonania rynku rolnego i poprawy jego struktury.

W ramach pierwszej grupy, obie izby:

1) sporządzają analizy, oceny, opinie i wnioski z zakresu produkcji rolnej oraz rynku rolnego oraz przedstawiają je organom administracji rządowej i jednostkom samorządu terytorialnego;

2) prowadzą doradztwo w zakresie działalności rolniczej, wiejskiego doradztwa domowego oraz uzyskania przez rolników dodatkowych dochodów;

3) kształtują zasady etyki i rzetelnego postępowania w dziedzinie działalności gospodarczej;

4) współdziałają z jednostkami prowadzącymi szkoły rolnicze, wspieranie ich działalności, inicjowanie powstawania nowych szkół i zmian w programach nauczania oraz współorganizowania praktyk;

5) wspierają międzynarodową współpracę we wszystkich sektorach rolnictwa oraz promowanie eksportu produktów rolnych;

6) współpracują $\mathrm{z}$ administracją publiczną $\mathrm{w}$ zakresie ochrony środowiska, zdrowia i wiejskiego dziedzictwa kulturowego.

W ramach drugiej grupy, obie izby:

1) gromadzą, przetwarzają i przekazują informacje gospodarcze na potrzeby producentów rolnych oraz innych przedsiębiorców;

2) przekazują informacje dotyczących rolnictwa społeczeństwu, informują o sprawach związanych z rolnictwem mających szczególne znaczenie dla ochrony środowiska, ochrony przyrody, ochrony zwierząt, ochrony praw konsumentów oraz popierają pro-

\footnotetext{
${ }^{18}$ Ustawa z dnia 5 czerwca 1998 r. o samorzqdzie powiatowym, Dz. U. Nr 91, poz.578.

${ }^{19}$ Ustawa z dnia 5 czerwca 1998 r. o samorzqdzie województwa, Dz. U. Nr 91, poz. 576.

${ }^{20}$ Ustawa z dnia 8 marca 1990 r. o samorzqdzie gminnym, Dz. U. Nr 142, poz. 1591.
} 
wadzenia dialogu z grupami społecznymi, dla których istotne znaczenie mają sprawy związane z rolnictwem.

W ramach trzeciej grupy, Wielkopolska Izba Rolnicza oraz Izba Rolnicza Północnej Nadrenii-Westfalii:

1) prowadzą działania na rzecz rynku rolnego oraz poprawy warunków zbytu płodów rolnych i produktów rolnych;

2) prowadzą analizę kosztów i produkcji rolnej;

3) podejmują działania na rzecz rozwoju infrastruktury rolnictwa i wsi oraz poprawy struktury agrarnej;

4) prowadzą listy rzeczoznawców oraz przyznają tytuły kwalifikacyjne w zakresie rolnictwa. Natomiast Izba Rolnicza Północnej Nadrenii-Westfalii różni się od Wielkopolskiej Izby Rolniczej w zakresie wykonywania następujących zadań:

1) występuje do organów administracji rządowej i organów administracji samorządowych $\mathrm{z}$ inicjatywami w zakresie regulacji prawnych dotyczących rolnictwa oraz opiniuje projekty tych przepisów;

2) podnosi kwalifikacje osób zatrudnionych w rolnictwie;

3) prowadzi szkolnictwo zawodowe i zawodowe dokształcanie młodej kadry zawodowej;

4) wspiera pracowników zatrudnionych w sektorze rolnictwa w sprawach społecznych i zawodowych;

5) współdziała (z głosem doradczym) w kwestiach: podziału, wykorzystania i uregulowania sprzedaży produktów rolnych; wspierania rolniczych spółdzielni, związków producentów rolnych, fuzji producentów rolnych, wprowadzenia produktów rolnych na inne regionalne rynki;

6) wspiera działalność administracji publicznej i wymiaru sprawiedliwości przez wydawanie opinii, powoływanie rzeczoznawców z dziedziny rolnictwa;

7) ustala dyrektywy dla rzeczoznawców i księgowych w sektorze rolnictwa;

8) uchwala przepisy i zarządzenia w administrowaniu i notowaniu cen na giełdzie;

9) odkrywa dodatkowe potencjały produkcji rolnej, form zbytu, dochodów ze sprzedaży produktów rolnych opartych na nowych surowcach, wykorzystuje energię odnawialną w wytwarzaniu produktów rolnych; rozszerza możliwości tworzenia różnych kombinacji podatku dochodowego dla zwiększenia sprzedaży produktów rolnych ${ }^{21}$.

Podkreślić należy, że ilość zadań własnych, a także zleconych izb rolniczych jest zmienna i zależy od dynamiki rozwoju rolnictwa. Na przykład w kraju związkowym Szlezwiku-Holsztynie weszła w życie ustawa o ochronie roślin z dnia 22 maja 2005 roku $^{22}$. W związku z tą ustawą Izbie Rolniczej tego landu doszły w 2008 r. dwa zadania zlecone, a mianowicie, ochrona roślin i pomnażanie zasobów leśnych. Waga tych nowych zadań jest tak znaczna, że w strukturze organizacyjnej Izby powstała nowa jednostka administracyjna, kierowana przez specjalnego członka zarządu (Geschaeftsfuehrer) ${ }^{23}$, który za realizację tych działań jest odpowiedzialny przed izbą rolniczą i rządem krajowym ${ }^{24}$.

\footnotetext{
${ }^{21}$ Gesetz über Landwirtschaftskammer Nordrhein-Westfalen v. 11.2.1949, GV NW. S. 53; Gesetz über Landwirtschaftskammer Nordrhein-Westfalen v. 23.12.2003, GV NW. S. 808.

${ }^{22}$ Pflanzenschutzgesetz v. 22.5.2005, BGB, 2005, 1658.

${ }^{23}$ R. Jahn, Gesetzesaenderungen im Kammerrecht 2007, Jahrbuch des Kammers - Berufsrechts 2007, Halle 2008, s. 164.

${ }^{24}$ Oprócz nowych kompetencji doprowadzono do zwiększenia zależności izby od władzy centralnej. Izba Rolnicza Szlezwiku-Holsztyna, realizując zadania zlecone przez administracje rządową, musi uzyskać zgodę ministerstwa rolnictwa i środowiska na kierunek i sposób realizowania owych zadań. Ministerstwo rolnictwa wspiera wypełnianie
} 
IV.

W celu realizowania zadań izby rolnicze, jako instytucje samorządu gospodarczego, powołują własne organy władzy, niezależne od innych organów administracji państwowej. Podobieństwo i różnice między strukturą organizacyjną Wielkopolskiej Izby Rolniczej a Izby Rolniczej Północnej Nadrenii-Westfalii można określić na podstawie kryterium przedmiotowego.

W Izbie Rolniczej Północnej Nadrenii-Westfalii organami Izby są: walne zgromadzenie, komisje, komisja główna, prezydent Izby oraz dyrektor ${ }^{25}$. Natomiast organami Wielkopolskiej Izby Rolniczej są: walne zgromadzenie, komisja rewizyjna, zarząd oraz rady powiatowe. Kadencja organów zarówno w Polsce, jak i w Niemczech trwa cztery lata. Członkami Izby Rolniczej Północnej Nadrenii-Westfalii i pozostałych izb rolniczych w RFN sa:

1) osoby fizyczne: właściciele, użytkownicy oraz dzierżawcy gruntów rolnych oraz ich współmałżonkowie;

2) osoby fizyczne właściciele, użytkownicy, dzierżawcy zakładów produkcji rolnej oraz ich współmałżonkowie;

3) członkowie rodziny, którzy współpracują z osobami w związku z punktem 1 i punktem 2;

a) osoby fizyczne zatrudnione $w$ rolnictwie,

b) osoby wykształcone w zawodach związanych $\mathrm{z}$ rolnictwem,

c) osoby prawne, które dłużej niż trzy miesiące prowadzą działalność na terenie funkcjonowania izby ${ }^{26}$.

W Polsce członkowie izby rolniczej nie stanowią jednolitego katalogu osób, tak jak w przypadku niemieckiej izby. Zdaniem Kazimierza Stróżczyka, przyczyną takiego stanu rzeczy jest traktowanie izby jako „formy samorządu producentów” bądź też jako zorganizowanej formy samorządu zawodu rolniczego ${ }^{27}$.

Jak wynika z ustawy z dnia 14 grudnia 1995 r. o izbach rolniczych o przynależności do izb rolniczych decyduje bycie płatnikiem podatku rolnego lub podatku dochodowego z działów specjalnych produkcji rolnej. Zatem jak stanowi ustawa, członkami samorządu rolniczego są: 1) rolnicy indywidualni (osoby fizyczne) i producenci rolni; osoby fizyczne i osoby prawne będące podatnikami podatku rolnego);

2) rolnicy indywidualni (osoby fizyczne) i producenci rolni (osoby fizyczne i osoby prawne będące podatnikami podatku dochodowego z działów specjalnych produkcji rolnej;

zadań poruczonych przez izbę przekazując do jej dyspozycji urzędników krajowych. Delegacja urzędników krajowych oznacza zatrudnienie ich jako pracowników izby; por. R. Jahn, Gesetzesaenderungen im Kammerrecht 2007 , s. 165. Regulacje prawne ustroju izb obejmują także poszerzanie składu personalnego izb. Proces poszerzania liczby członków izb samorządu gospodarczego rozpoczęto nowelizacją ustawy dotyczącej izb rzemieślniczych w 2005 r., która zwiększyła skład osobowy izby o partnerów życiowych pierwotnych członków izby. W 2007 roku izba w Hamburgu przyjęła niniejsze regulacje (co w znaczeniu prawnym oznaczało zalegalizowanie związków homoseksualnych), na mocy których stwierdzono, że członkiem izby jest każdy partner życiowy danego członka izby oraz partner życiowy, który współpracuje z zakładzie produkcji rolnej członka izby; por. R. Jahn, Gesetzesaenderungen im Kammerrecht 2007, s. 164-165.

${ }^{25}$ Ibidem, s. 165.

${ }^{26}$ Gesetz über Landwirtschaftskammer Nordrhein-Westfalen v. 11.2.1949, GV NW. S. 53; Gesetz über Landwirtschaftskammer Nordrhein-Westfalen v. 23.12.2003, GV NW. S. 808.

${ }^{27}$ K. Stróżczyk, Prawny model izb rolniczych w Polsce na tle rozwiqzań zachodnioeuropejskich, w: Rolnictwo w procesie integrowania Polski z Unia Europejska, t. II: Instytucje rolnicze w procesie przeobrażeń rynkowych, pod red. M. Adamowicza, Warszawa 1994, s. 69. 
3) członkowie rolniczych spółdzielni produkcyjnych ${ }^{28}$.

Zasady wyborcze do izby zostały uregulowane przez ministra rolnictwa kraju związkowego Północnej Nadrenii-Westfalii w Ordynacji Wyborczej do wyżej wymienionej izby ${ }^{29}$. Członkowie walnego zgromadzenia izby są wybierani spośród dwóch grup. W pierwszej grupie znajdują się właściciele gruntów rolnych oraz zakładów produkcji rolnej wraz ze swoimi członkami rodziny zatrudnionymi, w sektorze rolnictwa. Natomiast w drugiej grupie znajdują się osoby, które są zatrudnione w sektorze rolnictwa nieposiadające ani własności gruntowej, ani zakładów produkcji rolnej ${ }^{30}$. Na jej podstawie dla grupy wyborczej numer jeden i numer dwa są sporządzane dwie odrębne listy kandydatów. Każdy wyborca otrzymuje listę kandydatów startujących w wyborach zgodnie z przynależnością do grupy pierwszej lub do grupy drugiej, w której znajdują się pracownicy zatrudnieni w sektorze rolnictwa, ale nieposiadający własności gruntowej ani zakładów produkcji rolnej.

Wyborca przyporządkowany do jednej z tych dwóch grup wyborców nie ma prawa zagłosować na kandydatów z listy innej grupy. Wyborca nie oddaje swojego głosu na listę kandydatów, lecz na poszczególną osobę z tej listy. Należy skreślić ponad połowę liczby osób, które są wybierane do walnego zgromadzenia. Ponadto ustawodawca uregulował liczbę osób, które mają być wybrane do izby. Z pierwszej grupy wyborczej do walnego zgromadzenia musi pochodzić $2 / 3$ osób wybranych, natomiast $z$ drugiej grupy wyborczej $1 / 3$ członków walnego zgromadzenia ${ }^{31}$.

Jak przewiduje § 15 ustawy (z 11 lutego 1949 r.) o Izbie Rolniczej z Północnej Nadrenii-Westfalii statut powinien zawierać zapis o komisjach, które mogą być powołane przez walne zgromadzenie. Tylko komisja główna musi być niezwłocznie ujęta w statucie. Walne zgromadzenie określa, jakie komisje zostaną powołane oraz ich skład członkowski. Ponadto komisje same mogą wybierać dalszych członków spoza grona izby rolniczej. Osoba spoza izby, aby zostać członkiem komisji musi uzyskać zgodę komisji głównej. Statut izby rolniczej przewiduje także powołanie doradców resortowych. W celu usprawnienia prac nad konkretną uchwałą izba ma prawo powołać kilkuosobowe gremia ${ }^{32}$. Należy zaznaczyć, że komisje stanowią bardziej ciała doradcze i opiniodawcze dla izby, a nie organy wyznaczające kierunek jej działań ${ }^{33}$.

W Polsce, obowiązek ustalenia trybu przeprowadzania wyborów spoczywał na ministrze właściwym do spraw rolnictwa. Wybory w Polsce do izb rolniczych, po nowelizacji z dnia 21 czerwca 2001 r. są pośrednie, dwustopniowe i przeprowadzone w głosowaniu tajnym. Wybory dwustopniowe, czyli wybory powszechne do rad powiatowych, a później wybory pośrednie do walnego zgromadzenia spośród osób wybranych do powiatowych rad wskazują na zależność składu osobowego członków walnego zgromadzenia oraz delegatów do Krajowej Rady Izb Rolniczych od rad powiatowych. Bierne i czynne prawo wyborcze posiadają tylko jej członkowie. Zgłoszenie kandydata wymaga poparcia 50 członków izby. Członkowie izby mogą udzielić poparcia więcej niż jednemu kandydatowi, ale z zastrzeżeniem, że nie wycofają już raz danego głosu poparcia. Kandydować można tylko w jednym okręgu wyborczym.

\footnotetext{
${ }^{28}$ Ustawa z 14 grudnia 1995 r. o izbach rolniczych, Dz. U. Nr 1, poz. 3.

${ }^{29}$ Landwirtschaftskammer - Wahlordnung v. 28.12.1989, GV NW S. 6.

${ }^{30}$ Ibidem.

${ }^{31}$ Gesetz über Landwirtschaftskammer Nordrhein-Westfalen v. 11.2.1949, GV NW. S. 53; Gesetz über Landwirtschaftskammer Nordrhein-Westfalen v. 23.12.2003, GV NW. S. 808.

${ }^{32}$ Hauptsatzung der Landwirtschaftskammer Nordrhein-Westfalen vom 15. Dezember 2008, GV. NRW. S. 808.

${ }^{33}$ Ibidem.
} 
Na pierwszym posiedzeniu rady powiatowej izby dokonuje się wybór najpierw przewodniczącego powiatowej rady, a następnie delegata walnego zgromadzenia. Wybór przewodniczącego oraz delegata następuje zwykłą większością głosów spośród osób wybranych uprzednio do powiatowej rady ${ }^{34}$. Następnie spośród członków walnego zgromadzenia zostaje wybrany pięcioosobowy skład zarządu oraz pięcioosobowy skład komisji rewizyjnej ${ }^{35}$.

Najwyższą władzę w obu izbach sprawuje walne zgromadzenie będące organem uchwałodawczym i przedstawicielskim izby ${ }^{36}$. Do głównych zadań walnego zgromadzenia należą w szczególności: uchwalanie i zmiana statutu; wybór i odwołanie członków ${ }^{37}$; uchwalenie regulaminu obrad; podejmowanie uchwały w sprawie składki członkowskiej; założenie związku lub stowarzyszeń i przystąpienie do niego; wyrażenie zgody na uczestnictwo izby w organizacjach krajowych i międzynarodowych; podejmowanie uchwały w sprawie przyjęcia, w drodze porozumienia, zadań należących do właściwości administracji rządowej, przekazane ustawami lub na podstawie porozumień z właściwymi organami administracji rządowej oraz ustalenie zasad odpłatności za usługi świadczone przez izbę.

Walne zgromadzenie w Izbie Rolniczej Północnej Nadrenii-Westfalii ponosi odpowiedzialność za wykonywanie zadań zleconych. Nadzór nad walnym zgromadzeniem jest sprawowany na podstawie kryterium legalności. Funkcje kontrolne wobec izby rolniczej realizującej własne zadania i zlecone pełni rząd związkowy, natomiast wobec walnego zgromadzenia nadzór sprawują powołane przez nie komisje, pełniące funkcję doradczą i opiniodawczą dla władz kraju związkowego. Ich działalność umożliwia efektywniejsze wykonywania zadań przez izbę ${ }^{38}$.

Podział zadań komisji walnego zgromadzenia oraz komisji głównej nie został wprost uregulowany w ustawie. Odpowiedzialność za wyznaczenie kompetencji komisji spoczywa na walnym zgromadzeniu, które w zależności od określonych zadań, jakie ma do wypełniania, przekazuje część tych zadań do realizacji określonym komisjom lub komisji głównej ${ }^{39}$.

Władza wykonawcza w Izbie Rolniczej w Północnej Nadrenii-Westfalii jest wykonywana przez prezydenta izby. Jest to organ monokratyczny. W izbie nie występuje tak jak w przy-

\footnotetext{
${ }^{34}$ Por. R. Kmieciak, Wielkopolska Izba Rolnicza jako forma samorzqdu zawodowego i gospodarczego, Poznań 1995.

${ }^{35}$ R. Kmieciak, Samorzqd gospodarczy w Polsce. Rozważania na temat modelu ustrojowego, Poznań 2004, s. $160 \mathrm{i} \mathrm{nn}$.

${ }^{36} \mathrm{~W}$ nauce prawa izb - „Kammerecht” jest mowa o dwuznaczności terminologicznej w pojęciach izba rolnicza i walne zgromadzenie. W § 4 i § 13 ustawy o Izbie Rolniczej Północnej Nadrenii-Westfalii z 11 lutego 1949 r. uderza brak konsekwencji w stosowaniu tych dwóch pojęć. W § 13 jest zapisane, że walne zgromadzenie składa się z członków izby rolniczej. Niejasność budzi w tym przypadku stwierdzenie, kto jest organem izby a kto podmiotem publicznoprawnym. Ostatecznie wyjaśniono, że mówiąc o walnym zgromadzeniu mowa jest zawsze o organie władzy ustawodawczej izby rolniczej, natomiast izba jest związkiem publicznoprawnym. W wyżej wymienionej ustawie o organizacji izb samorządu rolniczego nie jest wyraźnie wskazane, kto jest członkiem izby rolniczej w Północnej Nadrenii-Westfalii. Istotny dla członkowstwa izby jest art. 4, który zawiera dwa terminy prawne: a) zgromadzenie plenarne (Vollversammlung), b) walne zgromadzenie (Hauptversammlung). Literalnie traktując ten artykuł stwierdzono, że w sensie prawnym tylko reprezentanci na zgromadzenie plenarne są członkami izby rolniczej jako korporacji publicznoprawnej. Również Kluth po analizie typów osobowości publicznoprawnej stwierdził że, członkami izby rolniczej są osoby, które posiadają prawo wyborcze do izby i płacą składki członkowskie, tylko członkowie izby mają uprawnienia i obowiązki na rzecz izby. W. Kluth, Entwicklungsgeschichte und aktuelle Rechtsgrundlagen..., op. cit., s. 104-105.

${ }^{37}$ W przypadku Wielkopolskiej Izby Rolniczej - członków komisji rewizyjnej oraz zarządu. Natomiast w przypadku Izby Rolniczej Północnej Nadrenii-Westfalii - członków komisji przedmiotowych.

${ }^{38}$ Gesetz über Landwirtschaftskammer Nordrhein-Westfalen v. 11.2.1949, GV NW. S. 53; Gesetz über Landwirtschaftskammer Nordrhein-Westfalen v. 23.12.2003, GV NW. S. 808

${ }^{39}$ W. Kluth, Entwicklungsgeschichte und aktuelle Rechtsgrundlagen..., op. cit., s. 105.
} 
padku Wielkopolskiej Izby Rolniczej zarząd izby ${ }^{40}$. Jego kompetencje przejęła komisja główna Izby Rolniczej Północnej Nadrenii-Westfalii. Ordynacja wyborcza wskazuje na sposób wyboru prezydenta izby. Stanowi o tym bezpośrednio $\S 16$ ust. 1 ustawy o izbie rolniczej z 11 lutego 1949 roku ${ }^{41}$. Prezydent Izby jest wybierany przez wszystkich członków izby większością 2/3 na okres trzyletniej kadencji. Ustawodawca określił też warunki, jakie musi spełniać kandydat na prezydenta izby. Po pierwsze, musi wywodzić się z pierwszej grupy wyborców i zgodnie z $§ 17$ ust. 1 musi być członkiem walnego zgromadzenia. Prezydent izby pełni równocześnie funkcję przewodniczącego walnego zgromadzenia i komisji głównej ${ }^{42}$. Na podstawie $\S 16$ ust. 4 prezydent izby wykonuje zadania z zakresu nadzoru nad izbą, reprezentuje izbę przed wymiarem sprawiedliwości oraz w innych sprawach niemających charakteru sądowniczego ${ }^{43}$.

Komisja główna jest kolegialnym organem wykonawczym, który realizuje zadania odpowiadające zarządowi izby rolniczej. Skład komisji głównej obejmuje 15 członków walnego zgromadzenia (2/3 z grupy pierwszej i 1/3 z grupy drugiej) $)^{44}$ i zastępcę prezydenta izby. Pracom komisji głównej przewodniczy prezydent izby. Do podstawowych zadań komisji głównej należy:

1) przygotowywanie projektów uchwał walnego zgromadzenia ${ }^{45}$;

2) przedkładanie projektu uchwały budżetowej izby, sprawozdania rocznego z działalności izby i rocznego sprawozdania finansowego izby;

3) opiniowanie kandydatów na członków komisji walnego zgromadzenia;

4) zajmowanie się doradztwem rolniczym;

5) podejmowanie uchwał w przedmiocie wniosków złożonych przez komisję walnego zgromadzenia lub doradców izby;

6) decydowanie o powołaniu gminnych biur izby ${ }^{46}$.

W Wielkopolskiej Izbie Rolniczej zadania niemieckiej Komisji Głównej realizuje zarząd $^{47}$. Zarząd Wielkopolskiej Izby Rolniczej wykonuje zadania w zakresie:

1) zwołuje obrady walnego zgromadzenia;

2) przygotowuje projekty uchwał walnego zgromadzenia;

3) opracowuje projekty budżetu, wraz z planem finansowym;

4) przedstawia walnemu zgromadzeniu roczne sprawozdania z działalności statutowej i finansowej oraz podejmuje czynności związane z działalnością izby (np. ustala zasady wynagrodzenia pracowników biura izby oraz ustala wysokość wynagrodzenia dyrektora biura);

${ }^{40}$ Zarząd jako organ władzy wykonawczej izby występuje np. w Izbie Rolniczej Szlezwiku-Holsztynu.

${ }^{41}$ Landwirtschaftskammer - Wahlordnung v. 28.12.1989, GV NW S. 6.

42 Ibidem.

${ }^{43}$ Ibidem.

${ }^{44}$ Gesetz über Landwirtschaftskammer Nordrhein-Westfalen v. 11.2.1949, GV NW. S. 53; § 17.

${ }^{45} \mathrm{~W} \S 11$ Hauptsatzung der landwirtschaftskammer Nordrhein-Westfalen vom 15.12.2008 wskazano, że projekty uchwał walnego zgromadzenia niecierpiące zwłoki są przygotowywane przez prezydenta izby a nie przez komisję główną.

${ }^{46}$ Hauptsatzung der landwirtschaftskammer Nordrhein-Westfalen vom 15.12.2008; w $§ 11$ wymieniono zadania komisji głównej. Ponadto komisja główna powołuje kierowników określonych działów izby. Wybór kandydata na owe stanowisko wymaga zgody ministra właściwego do spraw rolnictwa.

${ }^{47}$ Należy zaznaczyć, że tradycyjny organ, jakim jest Komisja Główna z powodzeniem funkcjonował jako organ Poznańskiej Izby Rolniczej do 1998 r. Szerzej: K. Walkowiak, Rola izb rolniczych w rozwoju wsi i rolnictwa w Polsce, Poznań 2004, s. 112. 
5) podejmuje uchwały w sprawie zaciągania kredytów i innych zobowiązań finansowych do wysokości ustalonej przez walne zgromadzenie;

6) zarządza wybory do walnego zgromadzenia.

Pomoc w realizacji prac zarządu zapewnia biuro izby, którym kieruje powołany przez zarząd dyrektor. Dyrektor w stosunku do pracowników biura wykonuje czynności służbowe przewidziane w prawie pracy. Dyrektor ponosi odpowiedzialność przed zarządem w zakresie realizowanych przez biuro zadań, do których zalicza się: dział finansowo-księgowy; stanowisko ds. zamówień publicznych oraz dział obsługi prawnej i kadrowej ${ }^{48}$.

Z kolei w Izbie Rolniczej Północnej Nadrenii-Westfalii walne zgromadzenie większością 2/3 głosów izby dokonuje wyboru dyrektora izby. Organ ten różni się od stanowiska dyrektora w Wielkopolskiej Izby Rolniczej. Jak stanowi § 18 ust. 1 ustawy o Izbie Rolniczej Północnej Nadrenii-Westfalii, jego kadencja trwa sześć lat. Powołanie dyrektora przez walne zgromadzenie wymaga następnie zatwierdzenia przez ministra właściwego do spraw rolnictwa kraju związkowego.

Dyrektor izby na podstawie art. 18 ust. 2 wspomnianej wyżej ustawy prowadzi bieżące sprawy izby. W ich wykonywaniu jest zobligowany do przestrzegania rad prezydenta izby zgodnych z uchwałami walnego zgromadzenia. Ponadto, podobnie jak dyrektor Wielkopolskiej Izby Rolniczej, pełni funkcję przełożonego służbowego wobec urzędników, osób zatrudnionych i innych pracowników izby ${ }^{49}$.

Dyrektor biura izby funkcjonuje nie tylko jako organ izby rolniczej, ale także jako organ administracji rządowej, wykonuje zadania zlecone przez rząd. W szczególności, z ramienia rządu kraju związkowego Północnej Nadrenii-Westfalii dyrektor izby jest odpowiedzialny za pozyskiwanie środków na wykonywanie zadań związanych z sektorem rolnictwa, ochroną roślin oraz realizowanie zadań, które są zlecone wyższym szczeblom wydziału leśnictwa w ramach ministerstwa rolnictwa wspomnianego landu. Ponadto, dyrektor izby jest organem administracji kraju związkowego, przed którym ponosi odpowiedzialność za utrzymywanie porządku rolniczego w kraju związkowym. Silna pozycja dyrektora izby najlepiej uwidacznia się przy podziale finansów izby rolniczej. W budżecie izba ma do dyspozycji od $42-48 \%$ swych środków finansowych na realizację zadań zleconych przez administrację landu ${ }^{50}$.

Do podstawowych uprawnień dyrektora należy: branie udziału w posiedzeniach walnego zgromadzenia, komisji głównej i komisji izby. Jest uprawniony do wydawania oświadczeń i wyjaśnień w danej sprawie. Ponadto w celu wykonywania zadań zleconych przez administrację Północnej Nadrenii-Westfalii ma prawo korzystania z instytucji i urzędników krajowych.

Ustawa o Izbie Rolniczej Północnej Nadrenii-Westfalii zakłada, że projekt budżetu tworzy komisja główna przy uwzględnieniu dochodów i wydatków dyrektora izby, jako przedstawiciela administracji kraju związkowego w izbie ${ }^{51}$. W przypadku Wielkopolskiej Izby Rolniczej zarząd izby jest odpowiedzialny za przygotowanie projektu budżetu izby wraz $\mathrm{z}$ planem finansowym.

Dochody i wydatki Izby Rolniczej Północnej Nadrenii-Westfalii są regulowane osobnym aktem prawnym: ustawą o wydatkach izby rolniczej (Umlagegesetz) ${ }^{52}$. Do podstawowych

\footnotetext{
${ }^{48}$ Statut Wielkopolskiej Izby Rolniczej z 25 stycznia 1999 r.

49 Ibidem.

${ }^{50}$ Gesetz über Landwirtschaftskammer Nordrhein-Westfalen v. 11.2.1949, GV NW. S. 53; Gesetz über Landwirtschaftskammer Nordrhein-Westfalen v. 23.12.2003, GV NW. S. 808.

${ }^{51}$ Ibidem.

52 Gesetz über eine Umlage der Landwirtschaftskammer Nordrhein-Westfalen v. 17.07.1951 GS. NW. S. 715.
} 
źródeł finansowania działalności izby rolniczej należy wymienić: dotacje państwowe, dotacje państwowe na realizację zadań zleconych przez administrację kraju związkowego, dotacje państwowe na realizację zadań własnych izby, wpływy z podatków oraz składki członkowskie.

Zgodnie z $§ 2$ wyżej wymienionej ustawy minister właściwy do spraw rolnictwa kraju związkowego Północnej Nadrenii-Westfalii ma obowiązek zatwierdzić wydatki izby, po wcześniejszym przyjęciu przez walne zgromadzenie uchwały w sprawie wydatków i dochodów izby. W § 3 ustawy uregulowano wysokość dotacji państwowych (Staatszuschüsse), jakie mogą być przekazane izbie ${ }^{53}$. Drugim źródłem dochodu izby są przydziały ze środków finansowych państwa (Staatszuweisungen). Zwrot kosztów administracyjnych obliczonych przez dyrektora izby, który realizuje powierzone mu zadania jako pełnomocnik rządu krajowego stanowi o szczególności tego urzędu ${ }^{54}$.

Składki członkowskie są płacone przez podatników podatku gruntowego - właścicieli i dzierżawców gruntów rolnych oraz przez członków ich rodzin. Opłata jest uiszczona rocznie. Najniższa opłata płacona na rzecz izby wynosi minimum 2,5 euro ${ }^{55}$.

Ustawa o Izbie Rolniczej Północnej Nadrenii-Westfalii nie wskazuje jednoznacznie, jakie podatki stanowią podstawę budżetu. W tym względzie ustawa o izbie rolniczej w Północnej Nadrenii-Westfalii odsyła do innej ustawy, mianowicie do ustawy o podatkach komunalnych z 21 października 1969 roku $^{56}$. Odnoszą się do tego paragrafy: $\S 2$ ust. $1, \S 5$ i $\S 6 d^{57}$.

Podobnie jest w przypadku Wielkopolskiej Izby Rolniczej. Środki finansowe Wielkopolskiej Izby Rolniczej pochodzą z: odpisów w wysokości 2\% od uzyskanych wpływów z tytułu podatku rolnego pobieranego na obszarze działania izby; dotacji na realizację zadań zleconych przez administrację rządową i samorządową; udziałów lub akcji spółek; darowizn, zapisów, dotacji i innych wpłat; składek członkowskich; opłat z tytułu świadczonych przez izbę usług; wpływów z oprocentowania rachunków bankowych oraz lokat.

Jak wynika z wywiadu przeprowadzonego w Wielkopolskiej Izbie Rolniczej podstawą finansowania są odpisy w wysokości $2 \%$ z tytułu podatku rolnego pobieranego na obszarze województwa wielkopolskiego. Część dochodów jest gromadzona na wyodrębnionym subkoncie Krajowej Rady Izb Rolniczych. Środki przekazywane do KRIR służą wyrównaniu dochodów izb, których wpływy z tytułu odpisu zostały zmniejszone wskutek ulg, zwolnień, odroczeń lub umorzeń podatku rolnego albo zaniechania poboru tego podatku lub jego raty ${ }^{58}$.

Podejmując ocenę izb rolniczych funkcjonujących w Polsce i w Republice Federalnej Niemiec, należy zwrócić uwagę na istotne różnice w zakresie kompetencji administracyjnych

\footnotetext{
${ }^{53}$ W budżecie izby na rok 2010 wskazano, że dotacje państwowe na realizowanie przez izbę zadań zleconych delegowanych przez administrację kraju związkowego wynoszą, tak jak w 2009 r., 58500000 euro. Natomiast na emerytalny system zaopatrzeniowy dla członków izby dotacje kraju związkowego w budżecie na rok 2010 wynoszą, tak samo jak w 2009 r., 18550000 euro.

${ }^{54} \mathrm{~W}$ budżecie izby na rok 2010 wskazano, że te dochody wynoszą 8050000 euro.

${ }^{55}$ Gesetz über eine Umlage der Landwirtschaftskammer Nordrhein-Westfalen v. 17.07.1951 GS. NW. S. 715. Wydatki izby można podzielić w następujący sposób: ok. 40\% środków jest przeznaczonych na zwrot kosztów administracyjnych, ok. 23\% środków pochodzi z przydziałów państwowych na realizację zadań własnych izby, 13\% pochodzi z dochodu administracyjnego izby, $10 \%$ to składki członkowskie (Umlage) oraz 14\% to pozostałe dochody izby.

${ }^{56}$ Kommunalabgabengesetz für das Land Nordrhein-Westfalen (KAG) vom 21. Oktober 1969, GV. NRW. S. 712.

${ }^{57}$ Ibidem.

${ }^{58}$ K. Walkowiak, Rola izb rolniczych $w$ rozwoju wsi..., op. cit., s. 110.
} 
polskiego i niemieckiego samorządu rolniczego. Ustawodawca wyposażył polskie izby rolnicze w osobowość publicznoprawną, obligatoryjne członkostwo i władztwo administracyjne, czyli zdolność do wykonywania zadań publicznych. Wskutek tego od strony formalnoprawnej polskie izby rolnicze, tak jak niemieckie instytucje samorządu rolniczego, są elementem struktury publicznej. Jednakże podobieństwo w zakresie modelu administracyjnego nie gwarantuje realizacji tych samych zadań. Problemem polskiego samorządu rolniczego jest brak przepisów wykonawczych, które umożliwiłby przejęcie zadań z zakresu samorządu gospodarczego. Dlatego też organizacja izb rolniczych w RFN mimo, że nie funkcjonują one we wszystkich landach, winna być ważnym punktem odniesienia dla polskiego ustawodawcy w zakresie kształtowania zadań polskich izb rolniczych oraz narzędzi do ich realizacji.

\section{Summary}

\section{The legal structure of agricultural self-governing bodies in Poland and the Federal Republic of Germany. A comparative study}

Two models of farmers' institutions have developed in Europe: a) the French model, resulting from the decentralization of public administration and taking the form of agricultural chambers, or corporations under public law, administratively imposing obligatory membership, and b) the Anglo-Saxon model of voluntary agricultural associations with no administrative power. The purpose of this paper is to compare the first model, using the example of the North Rhine-Westphalia Chamber of Agriculture and the Wielkopolska Chamber of Agriculture. The differences are presented in terms of their respective legal structures and the tasks each chamber performs in the state administration of FRG and Poland. 